\title{
PENGARUH PERTUMBUHAN ASET DAN STRUKTUR MODAL TERHADAP PROFITABILITAS PADA PERUSAHAAN SUB SEKTOR PERKEBUNAN YANG TERDAFTARDI BURSA EFEK INDONESIA
}

\author{
I Made Ariyasa ${ }^{1}$, Gede Putu Agus Jana Susila ${ }^{2}$, Ni Nyoman Yulianthini ${ }^{3}$ \\ ${ }^{1}$ Program Studi Manajemen, Jurusan Manajemen, Fakultas Ekonomi \\ Universitas Pendidikan Ganesha, Singaraja \\ e-mail: madeariyasa46@gmail.com, janosundiksha@yahoo.com,nyoman.yulianthini@undiksha.ac.id
}

\begin{abstract}
Abstrak
Penelitian ini bertujuan untuk memperoleh temuan eksplanatif yang teruji tentang, (1) besar pengaruh pertumbuhan aset terhadap profitabilitas, (2) besar pengaruh struktur modal terhadap profitabilitas, (3) besar pengaruh pertumbuhan aset terhadap stukrtur modal dan (4) besar pengaruh pertumbuhan aset dan strukutur modal terhadap profitabilitas. Rancangan penelitian yang digunakan dalam penelitian ini adalah kuantitatif kausal. Jumlah populasi yang digunakan dalam penelitian ini sebanyak 15 perusahaan yang terdaftar di sub sektor perkebunan bursa efek Indonesia. Metode analisis data yang digunakan dalam penelitian ini adalah analisis jalur. Hasil penelitian ini menunjukkan bahwa, (1) pertumbuhan aset berpengaruh positif dan tidak signifikan terhadap profitabilitas, (2) struktur modal berpengaruh negative dan signifikan terhadap profitabilitas, (3) pertumbuhan asset berpengaruh positif dan signifikan terhadap struktur modal, dan (4) pertumbuhan asset dan struktur modal berpengaruh signifikan terhadap profitabilitas.
\end{abstract}

Kata Kunci: pertumbuhan aset, profitabilitas, struktur modal

\begin{abstract}
This study aims to obtain explanative findings that are tested about, (1) the effect of asset growth on profitability, (2) the effect of capital structure on profitability, (3) the effect of asset growth on capital structure and (4) the effect of asset growth and capital structure to profitability. The research design used in this study is causal quantitative. The population used in this study is 15 companies listed in the Indonesian stock exchange plantation sub-sector. Data analysis method used in this study is path analysis. The results of this study indicate that, (1) asset growth has a positive and not significant effect on profitability, (2) capital structure has a negative and significant effect on profitability, (3) asset growth has a positive and significant effect on capital structure, and (4) growth assets and capital structure have a significant effect on profitability.
\end{abstract}

Keywords: asset growth, capital structure, profitability 


\section{Pendahuluan}

Pada era globalisasi saat ini yang cenderung dengan peningkatan teknologi dan diiringi dengan persaingan pasar bebas yang begitu ketat, maka kelangsungan hidup suatu perusahaan sangat tergantung pada kemampuan perusahaan atau organisasi tersebut dalam mengelola perusahaan secara efektif dan efisien. Adapun tujuan dari berdirinya sebuah perusahaan. Tujuan yang pertama adalah untuk mencapai keuntungan (laba) maksimal. Laba adalah kenaikan manfaat ekonomi selama satu periode akuntansi dalam bentuk pemasukan atau penambahan aktiva. Tujuan yang kedua adalah ingin memakmurkan pemilik perusahaan atau para pemilik saham. Namun dalam era globalisasi seperti sekarang ini, mengakibatkan persaingan antar perusahaan semakin ketat. Dengan semakin ketatnya persaingan anatar perusahaan, maka perusahaan-perusahaan semakin dituntut untuk terus bekerja keras demi menciptakan inovasi yang baru untuk dapat meningkatkan pertumbuhan ekonomi.

Pasar modal adalah tempat atau sarana bertemunya permintaan danpenawaran atas instrumen keuangan jangka panjang umumnya lebih dari satu tahun menurut Robert (2010). Pasar modal merupakan sarana pendanaan bagi perusahaan maupun institusi lain (misalnya pemerintah) dan sarana bagi kegiatan berinvestasi. Dalam pasar modal ini, perusahaan harus berusaha agar investor bersedia menanamkan modalnya ke dalam perusahaan dengan cara meyakinkan pihak investor untuk dapat memperoleh return atas invetasinya. Salah satu bidang investasi yang banyak diminati oleh para investor asing maupun dalam negeri di pasar modal adalah bentuk saham perusahaan-perusahaan yang go public.

Saat ini Indonesia semakin banyak jumlah perusahaan yang berkembang pesat. Baik yang bergerak dalam bidang industri, perdagangan, dan jasa. Setiap perusahaan baik yang skala kecil maupun skala besar mempunyai tujuan yang telah ditetapkan sebelumnya. Tidak terkecuali di Bursa Efek Indonesia, perusahaan- perusahaan yang terdaftar dikelompokkan ke dalam sembilan sektor. Salah satu sektor yang berperan penting di pasar modal Indonesia adalah sektor pertanian yang terdiri dari empat sub sektor, yaitu sub sektor tanaman pangan, sub sektor perkebunan, sub sektor perikanan, dan sub sektor peternakan. Diantara keempat sub sektor tersebut, sub sektor perkebunan merupakan kelompok yang berkembang baik dan mampu memberikan kontribusi yang cukup besar pada pembangunan ekonomi Indonesia.

Sub Sektor perkebunan merupakan salah satu bisnis strategis dan andalan dalam perekonomian Indonesia, bahkan pada masa krisis ekonomi. Agrobisnis sub sektor ini mempunyai kontribusi yang signifikan terhadap stabilitas ekonomi makro, pertumbuhan, penciptaan lapangan kerja, penerimaan devisa dari ekspor, dan sumber bahan baku bagi industri hilir hasil pertanian. Selain itu, perkebunan juga mempunyai peran penting bagi pembangunan pertanian Indonesia. Selain mampu menciptakan kesempatan kerja yang mengarah pada kesejahteraan masyarakat, sektor perkebunan juga sebagai sumber perolehan devisa negara. Indonesia merupakan salah produsen hasil-hasil perkebunan utama di dunia.

Selain beberapa uraian diatas, peneliti tertarik untuk melakukan penelitian di sub sektor perkebunan adalah nilai harga saham pada sub sektor ini terbilang mengalami sedikit peningkatan, akan tetapi dari ketiga sub sektor tersebut, sub sektor perkebunan yang mengalami peningkatan pertumbuhan aset paling rendah. Hal tersebut dapat dilihat bahwa tahun 2017 pertumbuhan aset perikanan $-30 \%$, kemudian meningkat sangat drastis pada tahun 2018 menjadi $212 \%$. Pada sub sektor pakan ternak, pertumbuhan aset pada tahun 2017 sebesar $-38 \%$ dan pada tahun 2018 meningkat menjadi 28\%. Sedangkan pada sub sektor pertumbuhan aset tahun 2017 sebesar $-33,07 \%$ dan pada tahun 2018 meningkat menjadi $24,22 \%$. Sehingga dapat diambil kesimpulan dari perbandingan data diatas bahwa pada sub sektor perkebunan mengalami peningatan pertumbuhan aset paling minim diantara 
dua sektor lainnya. Dalam penelitian ini, perusahaan sub sektor perkebunan digunakan sebagai subjek penelitian.

Rasio profitabilitas pada perusahaan sub sektor perkebunan menunjukkan penurun dari tahun 2017-2018. Pada tahun 2017 (ROE) perusahaan sub sektor perkebunan sebesar $0,09 \%$, dan rasio profitabilitas ini mengalami penurunan sebesar $3,06 \%$ yakni pada tahun 2018 rasio profitabilitas perusahaan sub sektor perkebunan sebesar $-2,97 \%$. Hal ini tidak sejalan dengan Pujawati (2015) yang menyatakan, semakin tinggi hasil pengembalian atas ekuitas berarti semakin tinggi pula jumlah laba bersih yang dihasilkan dari setiap rupiah dana yang tertanam dalam ekuitas, dengan kata lain pembayaran deviden kepada para pemegang saham akan semakin bertambah pula dan akan menyebabkan peningkatan harga saham.

Berdasarkan latar belakang dan rumusan masalah yang ingin dikaji dalam penelitian ini, maka tujuan yang ingin dicapai dalam penelitian ini adalah sebagai berikut: (1) Untuk mengetahui besar pengaruh pertumbuhan aset terhadap profitabilitas pada perusahaan sub sektor perkebunan yang terdaftar di Bursa Efek Indonesia, (2) Untuk mengetahui besar pengaruh struktur modal terhadap profitabilitas pada perusahaan sub sektor perkebunan yang terdaftar di Bursa Efek Indonesia, (3) Untuk mengetahui besar pengaruh pertumbuhan aset terhadap struktur modal pada perusahaan sub sektor perkebunan yang terdaftar di Bursa Efek Indonesia, (4) Untuk mengetahui besar pengaruh pertumbuhan aset dan struktur modal terhadap profitabilitas pada perusahaan sub sektor perkebunan yang terdaftar di Bursa Efek Indonesia.

Hasil penelitian ini diharapkan memberikan manfaat secara teorits dan manfaat secara praktis. (1) Manfaat Teoritis. Secara teoritis hasil penelitian ini diharapkan dapat memberikan bukti empiris mengenai pengaruh pertumbuhan aset dan strukutr modal secara simultan terhadap profitabilitas serta dapat digunakan sebagai refrensi untuk penelitian lebih lanjut. (2) Manfaat Praktis. Secara praktis penelitian ini dapat bermanfaat sebagai masukan dan dapat memberikan informasi yang diperoleh dari hasil pertumbuhan aset dan struktur modal secara simultan terhadap profitabilitas pada perusahaan sub sektor Perkebunan yang terdaftar di Bursa Efek Indonesia.

Aset merupakan aktiva yang digunakan untuk aktivitas operasional perusahaan. Semakin besar aset diharapkan semakin besar hasil operasional yang dihasilkan oleh perusahaan. Peningkatan asset yang diikuti peningkatan hasil operasi akan semakin menambah kepercayaan pihak luar terhadap perusahaan. Dengan meningkatnya kepercayaan pihak luar (kreditor) terhadap perusahaan, maka proporsi hutang semakin lebih besar daripada modal sendiri. Hal ini didasarkan pada keyakinan kreditor atas dana yang ditanamkan ke dalam perusahaan dijamin oleh besarnya asset yang dimiliki perusahaan (Robert Ang,1997).

Fahmi (2011) menyatakan bahwa, "perusahaan dengan tingkat pertumbuhan yang tinggi pada umumnya tergantung pada modal dari luar perusahaan. Pada perusahaan dengan tingkat pertumbuhan yang rendah kebutuhan baru relatif kecil sehingga dapat dipenuhi dari laba ditahan."

Menurut Hery (2015) menyatakan, "Perusahaan yang tumbuh dengan pesat harus lebih banyak mengandalkan modal eksternal. Lebih jauh lagi, biaya pengembangan untuk penjualan saham biasa lebih besar dari pada biaya untuk penerbitan surat utang yang mendorong perusahaan untuk lebih banyak mengandalkan utang. Namun, pada saat yang sama perusahaan tumbuh dengan pesat sering menghadapi ketidakpastian yang lebih besar, dan cenderung mengurangi keinginannya untuk menggunakan utang."

Dengan kata lain dari dua penjelasan di atas bahwa pertumbuhan perusahaan yang tinggi tergantung pada modal dari luar perusahaan, perusahaan yang tumbuh pesat mempunyai biaya pengembangan untuk penjualan saham lebih besar dari pada biaya untuk penerbitan surat hutang. Namun dengan perusahaan yang tumbuh pesat cenderung untuk mengurangi keinginan untuk menggunakan utang. 
H1: Ada pengaruh signifikan pertumbuhan aset dan struktur modal terhadap profitabilitas.

Menurut Prestyo (2011:143) menyatakan pertumbuhan perusahaan, "Variabel pertumbuhan dapat dilihat dari sisi penjualan, asset maupun laba bersih perusahaan. Meski dapat dilihat dari berbagaisisi, namun ketiganya menggunakan prinsip dasar yang sama di mana pertumbuhan dipahami sebagai kenaikan nilai di suatu periode relatif terhadap periode sebelumnya." Dari pernyataan diatas dapat ditarik kesimpulan bahwa pertumbuhan perusahaan dapat dilihat dari berbagai sisi namun bagaimana prinsip yang dipakai dalam perusahaan tersebut. Namun dari ketiga prinsip sama artinya yaitu untuk menilai kenaikan di suatu periode relatif terhadap periode sebelumnya.

Menurut Sawir (2001) menyatakan pertumbuhan aset, "Pertumbuhan perusahaan selalu identik dengan aset perusahaan (baik asset fisik seperti tanah, bangunan, gedung sertaaset keuangan seperti kas, piutang dan lain sebagaianya). Paradigma asset sebagai indikator pertumbuhan perusahaan merupakan hal yang lazim digunakan. Nilai aset dalam neraca menentukan kekayaan perusahaan."

Menurut Setiawan (2016) Asset growth menunjukkan bahwa aktiva yang digunakan dalam perusahaan, dimana manajer dalam bisnis perusahaan memperhatikan pertumbuhan investasi pada pendapatan setelah pajak dan mengharapkan kinerja yang lebih baik dalam pertumbuhan perusahaan.

Menurut Raya (2013) semakin besar total aset diharaphan semakin besar hasil operasional yang dihasilkan oleh perusahaan. Peningkatan total aset yang diikuti peningkataan hasil operasi akan semakin menambah kepercayaan pihak luar terhadap perusahaan. Dengan meningkatnya kepercayaan pihak luar terhadap perusaan, maka proporsi hutang semakin lebih besar dari pada modal sendiri. Hal ini didasarkan pada keyakinan kreditor atas dana yang ditanamkan kedalam perusahaan dijamin oleh besarnya total aset yang dimiliki perusahaan.

$\mathrm{H} 2$ : Ada pengaruh tidak signifikan pertumbuhan aset terhadap profitabilitas.

Struktur Modal adalah perimbangan atau perbandingan antara modal asing dengan modal sendiri. Modal asing dalam hal ini adalah hutang jangka panjang maupun jangka pendek. Sedangkan modal sendiri terbagi atas laba ditahan dan penyertaan kepemilikan perusahaan. Struktur modal yang optimal adalah struktur modal yang mengoptimalkan keseimbangan antara risiko dan pengembalian sehingga memaksimumkan harga saham. Untuk itu, dalam penetapan struktur modal suatu perusahaan perlu mempertimbangkan berbagai variabel yang mempengaruhinya.

Struktur modal merupakan masalah yang penting bagi perusahaan karena baik buruknya struktur modal akan mempunyai efek langsung terhadap posisi finansial perusahaan, terutama dengan adanya hutang yang sangat besar akan memberikan beban kepada perusahaan. Struktur modal menurut Sartono (2010:225) didefinisikan sebagai berikut: "Struktur modal merupakan perimbangan jumlah utang jangka pendek yang bersifat permanen, utang jangka panjang, saham preferen dan saham biasa." Jadi struktur modal merupakan perimbangan antara jumlah utang jangka pendek, utang jangka panjang, dan saham. Struktur modal menurut Sudana (2011:143) didefinisikan sebagai berikut: "Struktur modal (capital structure) berkaitan dengan pembelanjaan jangka panjang suatu perusahaan yang diukur dengan perbandinganutang jangka panjang dengan modal sendiri."Jadi struktur modal merupakan perbandingan antar utang jangka panjang dengan modal sendiri yang digunakan untuk pembelanjaan perusahaan.

Struktur modal menurut Fahmi (2011:106) didefinisikan sebagai berikut, "Struktur modal merupakan gambaran dari bentuk proporsi finansial perusahaan yaitu antara modal yang dimiliki yang bersumber dari utang jangka panjang (long-term liabilities) dan modal sendiri (shareholder's equity) yang menjadi sumber pembiayaan suatu perusahaan." Jadi struktur modal merupakan gabungan sumber dana perusahaan yang bersumber dari utang jangka panjang dan modal sendiri yang digunakan sebagai sumber pembiayaan 
perusahaan. Dari beberapa definisi yang telah dikemukakan oleh para ahli, dapat disimpulkan bahwa struktur modal merupakan proporsi keuangan antara utang jangka pendek, utang jangka panjang dan modal sendiri yang digunakan untuk pemenuhan kebutuhan belanja perusahaan.

H3: Ada pengaruh signifikan struktur modal terhadap profitabilitas.

Pertumbuhan aset pada suatu perusahaan berpengaruh positf terhadap profitabilitas, begitu juga dengan struktur modal yang tinggi makaakan berpengaruh postif terhadap profitabilitas. Semakin tinggi struktur modal dan semakin baik pertumbuhan aset dari perusahaan akan mempengaruhi profitabilitas dari setiap perusahaan. Menurut Jonidkk (2010) dan Margaretha bahwa pertumbuhan asetdan struktur modal memiliki pengaruh postif terhadap profitabilitas. Leverage Operasi, Perusahaan dengan leverage operasi yang lebih rendah akan lebih mampu menerapkan leverage keuangan karena perusahaan tersebut akan memiliki risiko usaha yang lebih rendah.

H4: Ada pengaruh signifikan pertumbuhan aset terhadap struktur modal.

\section{Metode}

Desain penelitian ini merupakan kuantitatif kausal yaitu penelitian yang menekankan pada pengujian teori-teori melalui pengukuran variabel-variabel penelitian dengan angka dan melakukan analisis data dengan prosedur statistik. Pendekatankuantitatif kausal merupakan penelitian pendekatan ilmiah terhadap pengambilan keputusan manajerial dan ekonomi yang bertujuan untuk mendapatkan bukti hubungan sebab akibat atau pengaruh dari variabelvariabel penelitian. Variabel bebas yang digunakan dalam penelitian ini meliputi: pertumbuhan aset $\left(X_{1}\right)$ dan struktur modal $\left(X_{2}\right)$. Sedangkan variabel terikat yang digunakan adalah profitabiltias $(\mathrm{Y})$.

Populasi merupakan wilayah generalisasi yang terdiri dari objek atau subjek yang memiliki kuantitas dan karakteristik tertentu yang ditetapkan oleh peneliti untuk dipelajari dan kemudian ditarik kesimpulannya (Sugiyono, 2011). Adapun populasi dari penelitian ini adalah perusahaan sub sektor perkebunan yang terdaftar di Bursa Efek Indonesia (BEI) yang mempublikasikan laporan keuangan tahunan secara lengkap sebanyak 15 perusahaan. Penelitian ini merupakan penelitian populasi karena seluruh perusahaan sub sektor perkebunan yang terdaftar di Bursa Efek Indonesia menjadi subjek penelitian. Untuk memperoleh data di lapangan maka perlu dilakukan pengumpulan data. Teknik pengumpulan data yang digunakan penulis dalam penelitian ini yaitu menggunakan pencatatan dokumen. Data yang diperoleh merupakan data sekunder yang langsung dapat diakses melalui www.idx.co.id dan www.bi.go.id. Teknik pengumpulan data ini merupakan pengumpulan data dengan cara mencatat data yang berhubungan dengan masalah yang akan diteliti dari dokumen-dokumen yang dimiliki perusahaan. Teknik pengumpulan data yang digunakan dalam penelitian ini adalah metode pencatatan dokumen. Metode ini merupakan teknik pengumpulan data dengan mengambilan catatan atau laporan historis yang telah tersusun dalam arsip (data dokumenter) yang dipublikasikan dan yang tidak dipublikasikan. Data dalam penelitian ini meliputi bahan-bahan yang berhubungan dengan topik penelitian yang diperoleh dari perusahaan seperti pelatihan yang diberikan perusahaan, biaya yang dikeluarkan untuk melaksanakan pelatihan, sumbangan kinerja yang disumbangkan oleh karyawan kepada perusahaan sebelum dan sudah dilaksanakanya pelatihan.Metode analisis data yang digunakan dalam penelitian ini adalah penelitian deskriptif dengan pendekatan kuantitatif.

Analisis data yang digunakan yaitu analisis jalur. Menurut Ghozali (2011:249) analisis jalur merupakan perluasan dari analisis regresi untuk menaksir hubungan kausalitas antar variabel yang telah ditetapkan sebelumnya berdasarkan teori. Dalam penelitian ini variabel pertumbuhan aset dan struktur modal berpengaruh terhadap profitabilitas. Untuk membantu proses pengolahan data secara cepat dan tepat, maka pengolahan datanya dilakukan 
dengan menggunakan program Statistical Package for Social Science (SPSS) for Windows release 16 .

\section{Hasildan Pembahasan}

\section{Hasil}

Analisis jalur digunakan untuk mengetahui pengaruh pertumbuhan aset dan struktur modal terhadap profitabilitas pada perusahaan sub sektor perkebunan yang terdaftar di Bursa Efek Indonesia. Hasil perhitungan statistik dilakukan dengan memasukkan angka pada masing-masing variabel yang terlebih dahulu data ordinal ditransformasi menjadi data interval. Berdasarkan hasil perhitungan uji statistik analisis jalur dengan menggunakan bantuan program Statistical Package for Social Science (SPSS) 26.0 For Windows maka diperoleh hasil perhitungan SPSS dapat dilihat mengenai sumbangan pengaruh pertumbuhan aset, struktur modal dan profitabilitas. Untuk hubungan pengaruh antara pertumbuhan aset, struktur modal dan profitabilitas pada perusahaan sub sektor perkebunan yang terdaftar di bursa efek Indonesiadapatdilihatpadagambardibawahini.

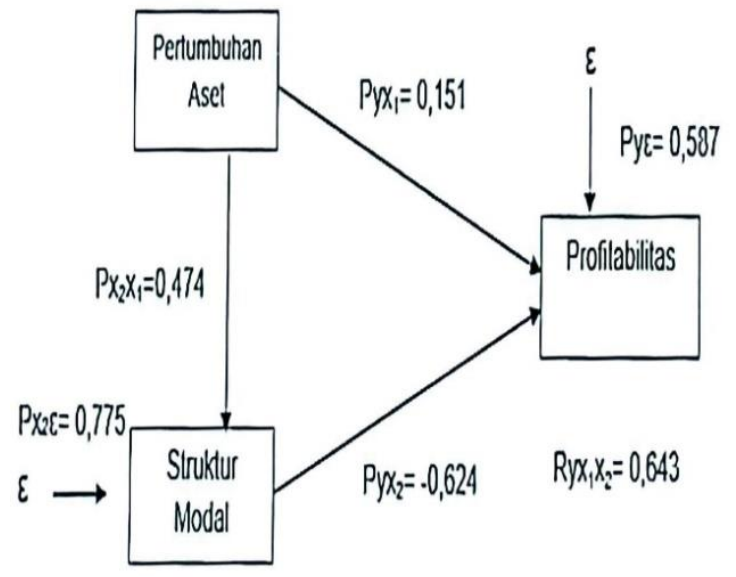

Gambar 1. Pengaruh Variabel Pertumbuhan Aset $\left(X_{1}\right)$ dan Struktur Modal $\left(X_{2}\right)$ terhadap Profitabilitas $(\mathrm{Y})$

Berdasarkan hasil perhitungan uji statistik analisis jalur, menunjukkan bahwa pertumbuhan aset berpengaruh positif namun tidak signifkan dengan profitabilitas. Besar hubungan pengaruh pertumbuhan aset terhadap profitabilitas adalah 15,10\% sedangkan besar sumbangan pengaruh dari pertumbuhan aset terhadap profitabilitas secara langsung adalah $2,3 \%$ dan besar pengaruh total pertumbuhan aset terhadap profitabilitas sebesar $2,72 \%$. Besar sumbangan pengaruh tidak langsung pertumbuhan aset terhadap profitabiltas melalui struktur modal sebesar $-2,95 \%$.

Berdasarkan hasil perhitungan uji statistik analisis jalur, menunjukkan bahwa ada pengaruh struktur modal secara negatif terhadap profitabilitas. Besar hubungan pengaruh struktur modal terhadap profitabilitas adalah $-62,40 \%$ dan besar sumbangan pengaruh struktur modal terhadap profitabilitas sebesar $38,9 \%$.

Berdasarkan hasil perhitungan uji statistik analisis jalur, menunjukkan bahwa ada pengaruh pertumbuhan aset terhadap struktur modal. Besar hubungan pengaruh pertumbuhan aset terhadap struktur modal adalah $47,40 \%$.

Berdasarkan hasil perhitungan uji statistik analisis jalur, menunjukkan bahwa pertumbuhan aset dan struktur modal secara bersama-sama berpengaruh secara positif terhadap profitabilitas pada perusahaan sub sektor perkebunan yang terdaftar di Bursa Efek Indonesia. Besar hubungan pengaruh pertumbuhan aset dan struktur modal terhadap profitabilitas adalah $64,30 \%$, sedangkan besar sumbangan pengaruh secara total pertumbuhan aset dan struktur modal terhadap profitabilitas sebesar $41,30 \%$. Besar 
sumbangan pengaruh lain pertumbuhan aset dan struktur modal terhadap profitabiltas sebesar $58.70 \%$.

\section{Pembahasan}

Berdasarkan penelitian yang telah dilakukan, maka diperoleh temuan bahwa variabel pertumbuhan aset dan struktur modal secara bersama-sama berpengaruh secara positif terhadap profitabilitas pada perusahaan sub sektor perkebunan yang terdaftar di Bursa Efek Indonesia. Pertumbuhan aset pada suatu perusahaan berpengaruh positf terhadap profitabilitas, begitu juga dengan struktur modal yang tinggi maka akan berpengaruh postif terhadap profitabilitas. Semakin tinggi struktur modal dan semakin baik pertumbuhan aset dari perusahaan akan mempengaruhi profitabilitas dari setiap perusahaan. Menurut Joni (2010) bahwa pertumbuhan aset dan struktur modal memiliki pengaruh positif terhadap profitabilitas.

Penelitian mengenai pengaruh struktur modal terhadap profitabilitas, diperoleh hasil ada pengaruh struktu modal secara negatif terhadap profitabilitas pada perusahaan sub sektor perkebunan yang terdaftar di Bursa Eefek Indonesia. Profitabilitas memiliki pengaruh negatif dengan utang, artinya ketika profit yang diperoleh perusahaan meningkat maka perusahaan tidak ikut meningkatkan utangnya, karena kemampuan menghasilkan profit yang tinggi sehingga perusahaan tidak perlu lagi untuk mencari pinjaman dari luar. Semakin tinggi profit suatu perusahaan maka proporsi ekuitas semakin meningkat atau proporsi pinjaman semakin menurun. Hal ini sesuai dengan packing order theory yang mana teori ini lebih menyukai pendanaan internal. Penelitian dahulu yang mendukung teori ini yaitu Adaskou (2015), Matemilola, et al (2012) serta Ella, dkk (2015).

Penelitian mengenai pengaruh dari variabel pengaruh pertumbuhan aset terhadap profitabilitas, diperoleh hasil variabel pengaruh pertumbuhan aset secara positif terhadap profitabilitas pada perusahaan sub sektor perkebunan yang terdaftar di Bursa Efek Indonesia. Hasil penelitian ini sejalan dengan teori yang disampaikan oleh Hasibuan (2010) menyatakan bahwa pertumbuhan aset mempengaruhi tingkat profitabilitas dari perusahan. Kajian empirik yang turut mendukung temuan penelitian ini adalah hasil penelitian yang dilakukan oleh Wiratama dan Sintaasih (2013) dan Yakub, dkk. (2014) yang menyatakan bahwa pertumbuhan aset berpengaruh secara positif terhadap profitabilitas.

Hasil penelitian selanjutnya yang diperoleh ada pengaruh pertumbuhan aset terhadap struktur modal. Besar hubungan pengaruh pertumbuhan aset terhadap struktur modal. Dalam penelitian ini, tentunya ada beberapa keterbatasan, meskipun peneliti telah berusaha mengembangkan penelitian ini sedemikian rupa. Adapun beberapa keterbatasan dalam penelitian ini diantaranya: (1) variabel bebas dalam penelitian ini masih terbatas, hanya menggunakan pertumbuhan aset, struktur modal dan profitabilitas, sehingga diharapkan untuk menggunakan variabel bebas lain yang dapat mempengaruhi return saham, (2) sampel yang digunakan hanya sebanyak15 perusahaan dengan dua tahun periode yaitu tahun 2017-2018. Diharapkan dapat menggunakan 3-4 tahun untuk selanjutnya.

\section{Simpulan dan Saran Simpulan}

Berdasarkan hasil dan pembahasan yang telah dilakukan, maka dapat ditarik beberapa simpulan sebagai berikut: (1) Pertumbuhan aset tidak memiliki hubungan yang signifikan terhadap profitabilitas pada perusahaan sub sektor perkebunan yang terdaftar di Bursa Efek Indonesia, (2) Struktur modal berpengaruh negatif dan signifikan terhadap profitabilitas pada perusahaan sub sektor perkebunan yang terdaftar di Bursa Efek Indonesia, (3) Pertumbuhan aset berpengaruh positif dan signifikan terhadap struktur modal pada perusahaan sub sektor perkebunan yang terdaftar di Bursa Efek Indonesia, (4) 
Pertumbuhan aset dan struktur modal berpengaruhsignifikan terhadap profitabilitas pada perusahaan yang terdaftar di Bursa Efek Indonesia.

\section{Saran}

Berdasarkan simpulan yang telah dikemukakan, maka dapat diajukan saran yaitu sebagai berikut: (1) Bagi pihak perusahaan sub sektor perkebunan, diharapkan dalam memaksimalkan return saham perlu mengoptimalkan penggunaan hutang, serta memperhatikan kebijakan investasi maupun kebijakan impor yang diterapkan perusahaan sehingga akan lebih mengoptimalkan return saham perusahaan, (2) Bagi peneliti lain, diharapkan menambah rentang waktu penelitian karena penelitian ini hanya menggunakan periode pengamatan selama 2 tahun yaitu tahun 2017-2018.

Dengan penggunaan rentang waktu penelitian yang lebih lama sehingga akan mendapatkan hasil penelitian yang lebih baik, kemudian diharapkan peneliti selanjutnya untuk menambahkan lagi atau meneliti variabel lain yang memiliki pengaruh terhadap return saham, karena variabel yang digunakan pada penelitian ini masih terbatas.

\section{Daftar Pustaka}

Ambarwati, Sri Dwi Ari. 2010. Manajemen Keuangan Lanjut. Yogyakarta: Graha Ilmu.

Ang, Robert. 2010. Buku Pintar Pasar Modal Indonesia. Jakarta: Mediasoft Indonesia.

Bank Indonesia. Website: http://www.bi.go.id. diakses tanggal 12 Desember

Bursa Efek Indonesia. Website: http://www.idx.co.id. diakses tanggal 12 Desember

Fahmi, Irham. 2011. Analisis Laporan Keuangan. Bandung: Alfabeta.

Ghozali, Imam. 2011. Aplikasi Analisis Multivariate dengan Program IBM SPSS19. Semarang: Universitas Diponogoro.

Hery. 2015. Analisis Kinerja Manajemen. Jakarta: PT Grasindo.

Julianvidiani, Tjikouwa. 2012. Analisis Pertumbuhan Aset dan Struktur modal yang Mempenaruhi Profitabilitas Perusahaan Pada PT. Semen Tonasa do Pangkep. Makasar: Universitas Hasanuddin.

Kamaludin dan Indriani, Rini. 2012. Manajemen Keuangan Konsep Dasar dan Penerapannya. Bandung: Mandar Maju.

Kasmir. 2010. Pengantar Manajemen Keuangan. Jakarta: Prenadamedia Group

Kurnia, Ade dan Isynuwardhana Deannes. (2015). "Pengaruh Return On Asset (ROA), Debt To Equity Ratio (DER) dan Size Perusahaan Terhadap Return Saham (Studi Kasus Pada Perusahaan Sektor Property dan Real Estate yang Terdaftar di Bursa Efek Indonesia Periode 2011-2014)". E-Proceeding of Management, Volume 2, Nomor 3 (hlm. 3337-3344), ISSN: 2355-9357.

Laksita Asmi, Tri. (2014). "Current Ratio, Debt To Equity Ratio, Total Asset Turn Over, Return On Asset, Price To Book Value Sebagai Faktor Penentu Return Saham". Management Analysis Journal, Volume 3, Nomor 2 (hlm. 1-12), ISSN: 2252-6552.

Mankiw, N. Gregory. 2006. Makroekonomi Edisi Keenam. Jakarta: Erlangga.

Moeljadi, 2006. Manajemen Keuangan. Jilid 1. Malang: Bayumedia

Murni, Asfia. 2009. Ekonomika Makro Edisi Revisi. Bandung: PT Refika Aditama.

Nurhakim S, Anistia dkk. (2016). "Pengaruh Profitabilitas Dan Inflasi terhadap Return Saham pada Industri Farmasi yang Terdaftar di BEI Periode 2011-2014". e-Proceeding of Management, Volume 3, Nomor 1, (hlm. 206-2013), ISSN: 2355-9357. 
Moeljadi, 2006. Manajemen Keuangan. Jilid 1. Malang: Bayumedia

Murni, Asfia. 2009. Ekonomika Makro Edisi Revisi. Bandung: PT Refika Aditama.

Nurhakim S, Anistia dkk. (2016). "Pengaruh Profitabilitas Dan Inflasi terhadap Return Saham pada Industri Farmasi yang Terdaftar di BEI Periode 2011-2014". e-Proceeding of Management, Volume 3, Nomor 1, (hlm. 206-2013), ISSN: 2355-9357.

Nurhayani Aisah, Ayu dan Kastawan Mandala. (2016). "Pengaruh ReturnOn Equity, Earning Per Share, Firm Size dan Operating Cashflow terhadap Return Saham". E-Jurnal Manajemen Unud, Volume 5, Nomor, 11 (hlm.6907-6936), ISSN: 2302-8912.

Pujawati, Eka, dkk. (2015). "Pengaruh Nilai Tukar Rupiah terhadap Return Saham dengan Profitabilitas sebagai Variabel Intervening". E-Jurnal Ekonomi dan Bisnis Universitas Udayana, Volume 4, Nomor 04 (hlm. 220-242), ISSN : 2337-3067.

Prabarsari, Yuke dan Hadri Kusuma. 2005. Faktor-Faktor Yang Mempengaruhi Struktur Modal Pada Perusahaan Maufakh Go Publik Yang Terdaftar di Bursa Efek Jakarta. Sumergi, Edisi Khusus On Finance: hal 1-15. 